\title{
Prenatal mold exposure is associated with development of atopic dermatitis in infants through allergic inflammation ${ }^{\text {is }}$
}

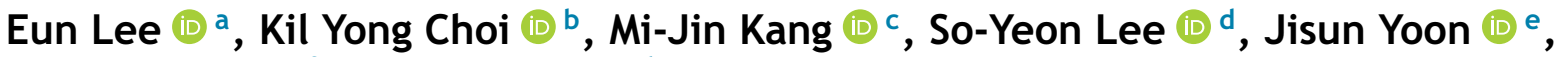 \\ Hyun-Ju Cho (i) ${ }^{f}$, Sungsu Jung (i) ${ }^{d}$, Si Hyeon Lee ${ }^{c}{ }^{c}$, Dong In Suh (i) $g$,

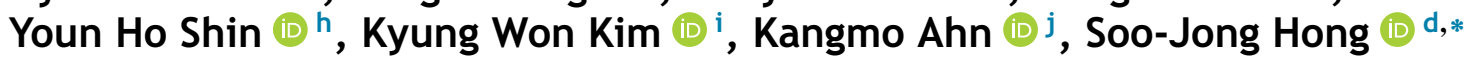

\footnotetext{
a Chonnam National University Hospital, Chonnam National University Medical School, Department of Pediatrics, Gwangju, Republic of Korea

b Pusan National University, Department of Environmental Engineering, Busan, Republic of Korea

c University of Ulsan College of Medicine, Asan Institute for Life Sciences, Seoul, Republic of Korea

d University of Ulsan College of Medicine, Childhood Asthma and Atopy Center, Department of Pediatrics, Seoul, Republic of Korea

e Mediplex Sejong Hospital, Department of Pediatrics, Incheon, Republic of Korea

f International St. Mary's Hospital, Catholic Kwandong University, Department of Pediatrics, Incheon, Republic of Korea

' Seoul National University College of Medicine, Department of Pediatrics, Seoul, Republic of Korea

h CHA Medical Center, CHA University School of Medicine, Department of Pediatrics, Seoul, Republic of Korea

i Severance Children's Hospital, College of Medicine, Yonsei University, Department of Pediatrics, Seoul, Republic of Korea

j Sungkyunkwan University School of Medicine, Samsung Medical Center, Department of Pediatrics, Seoul, Republic of Korea
}

Received 25 March 2018; accepted 30 July 2018

Available online 20 September 2018

\section{KEYWORDS \\ Allergic \\ inflammation; \\ Atopic dermatitis; \\ Environment; \\ Mold; \\ Mycobiome; \\ Prenatal}

\begin{abstract}
Objective: Mold exposure in early life may be associated with development of atopic dermatitis; however, studies of this link are inconclusive and evidence for the underlying mechanism(s) is lacking. This study identified the association between the time of mold exposure and development of atopic dermatitis and investigated the underlying mechanisms.

Method: The association between atopic dermatitis and mold exposure was examined in the Cohort for Childhood Origin of Asthma and Allergic Diseases birth cohort study $(n=1446)$. Atopic dermatitis was diagnosed at 1 year of age by pediatric allergists. Exposure to mold was assessed by questionnaire. The Illumina MiSeq platform was used to examine the environmental mycobiome in 20 randomly selected healthy infants and 20 infants with atopic dermatitis at 36 weeks of gestation.
\end{abstract}

\footnotetext{
2. Please cite this article as: Lee E, Choi KY, Kang M-J, Lee S-Y, Yoon J, Cho H-J, et al. Prenatal mold exposure is associated with development of atopic dermatitis in infants through allergic inflammation. J Pediatr (Rio J). 2020;96:125-31.

* Corresponding author.

E-mail: sjhong@amc.seoul.kr (S. Hong).
} 


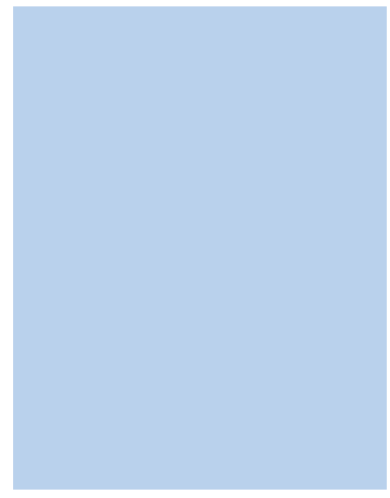

\section{PALAVRAS-CHAVE \\ Reação alérgica; Dermatite atópica; Ambiente; Mofo; Microbioma; Pré-natal}

Results: Prenatal, but not postnatal, mold exposure was significantly associated with atopic dermatitis (adjusted odds ratio, 1.36; 95\% confidence interval, 1.01-1.83). Levels of total serum IgE at 1 year of age were higher in infants with atopic dermatitis exposed to mold during pregnancy than in healthy infants not exposed to mold during pregnancy $(p=0.021)$. The relative abundance of uncultured Ascomycota was higher in infants with atopic dermatitis than in healthy infants. The relative abundance of uncultured Ascomycota correlated with total serum lgE levels at 1 year of age $(r=0.613, p<0.001)$.

Conclusion: Indoor mold exposure during the fetal period is associated with development of atopic dermatitis via IgE-mediated allergic inflammation. Avoidance of mold exposure during this critical period might prevent the development of atopic dermatitis.

(c) 2018 Sociedade Brasileira de Pediatria. Published by Elsevier Editora Ltda. This is an open access article under the CC BY-NC-ND license (http: / / creativecommons.org/licenses/by-nc-nd/ $4.0 /)$

Exposição pré-natal a mofo está associada ao desenvolvimento de dermatite atópica em neonatos por reação alérgica

\section{Resumo}

Objetivo: A exposição ao mofo no início da vida pode estar associada ao desenvolvimento de dermatite atópica; contudo, os estudos sobre esse vínculo são inconclusivos e faltam evidências dos mecanismos subjacentes. Identificamos a associação entre o momento da exposição ao mofo e o desenvolvimento de dermatite atópica e investigamos os mecanismos subjacentes.

Método: A associação entre dermatite atópica e exposição a mofo foi examinada em um estudo de coorte de nascimento da Origem da Asma e de Doenças Alérgicas em Crianças (COCOA) $(n=1446)$. A dermatite atópica foi diagnosticada em pacientes com um ano de vida por pediatras alergistas. A exposição ao mofo foi avaliada por um questionário. A plataforma Illumina MiSeq foi utilizada para examinar o microbioma ambiental em 20 neonatos saudáveis escolhidos aleatoriamente e 20 com dermatite atópica a 36 semanas de gestação.

Resultados: A exposição pré-natal, porém não pós-natal, ao mofo foi significativamente associada à dermatite atópica (razão de chances ajustada, 1,36; intervalo de confiança de 95\%, $1,01-1,83)$. Os níveis séricos totais de Imunoglobulina $E$ (IgE) no primeiro ano de vida foram maiores em neonatos com dermatite atópica expostos a mofo durante a gravidez do que em neonatos não expostos a mofo durante a gravidez $(p=0,021)$. A abundância relativa de Ascomycota não cultivado foi maior em neonatos com dermatite atópica do que em neonatos saudáveis. A abundância relativa de Ascomycota não cultivado correlacionou-se com os níveis séricos totais de IgE no primeiro ano de vida $(r=0,613, p<0,001)$.

Conclusão: A exposição ao mofo no ambiente domiciliar durante a gravidez está associada ao desenvolvimento de dermatite atópica por meio de reação alérgica mediada por lgE. A prevenção à exposição ao mofo durante o período crítico da gravidez pode prevenir o desenvolvimento de dermatite atópica.

(C) 2018 Sociedade Brasileira de Pediatria. Publicado por Elsevier Editora Ltda. Este é um artigo Open Access sob uma licença CC BY-NC-ND (http: / / creativecommons.org/licenses/by-nc-nd/4. $0 /)$.

\section{Introduction}

The prevalence of atopic dermatitis (AD) has increased according to region and socioeconomic status. ${ }^{1-3}$ Diverse environmental factors may contribute to the increased prevalence of $A D$, whereas a healthy diet and application of emollients might play a role in prevention. ${ }^{4}$

Among diverse environmental factors, mold exposure during early life is a potential risk factor for development of allergic diseases, including $A D$, although studies are inconclusive. 5,6 The inconsistent results might be attributable at least in part to differences in the timing of mold exposure. Like bacterial exposure, ${ }^{7}$ mold exposure, particularly during critical periods of gestation, may play a role in shaping the immune system, thereby affecting development of AD. Previous studies of the association between mold exposure and development of $A D$ focused on the effect of the skin mycobiome, including Malassezia species, on $\mathrm{AD} .^{8}$ However, studies of the association between exposure to environmental mold and $A D$ are lacking, and the immunomodulatory effects of mold exposure remain poorly understood.

Therefore, the aim of this study was to examine the association between the timing of mold exposure and development of $A D$, and to investigate the mechanisms underlying the relationship between indoor mold exposure, particularly during critical gestational periods, and development of $A D$. 
Table 1 Demographic characteristics of the study population.

\begin{tabular}{ll}
\hline Variable & $n(\%)$ or mean \pm SD \\
\hline Number & 1446 \\
Maternal age (years) & $33.04 \pm 3.54$ \\
Parental history of allergic disease & \\
$\quad$ No & $1160(70.2)$ \\
$\quad$ Yes & $492(29.8)$ \\
Birth season & \\
$\quad$ Spring & $314(21.7)$ \\
Summer & $327(22.6)$ \\
$\quad$ Autumn & $360(24.9)$ \\
$\quad$ Winter & $445(30.8)$ \\
Maternal educational level & \\
$\quad \leq$ High school & $76(5.3)$ \\
$\quad \leq$ University & $1053(72.8)$ \\
$\quad \geq$ Graduate school & $316(21.9)$ \\
Child's gender & \\
Boy & $685(47.4)$ \\
Girl & $761(52.6)$ \\
Gestational age (weeks) & $39.18 \pm 1.20$ \\
\hline
\end{tabular}

SD, standard deviation.

\section{Materials and methods}

\section{Study population}

The study was performed from November 2008 to December 2015 as a part of the prospective Cohort for Childhood Origin of Asthma and Allergic Diseases (COCOA) birth study (Table 1). ${ }^{9} \mathrm{AD}$ in infants aged 1 year was diagnosed by pediatric allergists using the criteria of Hanifin and Rajka. ${ }^{10}$ The SCORing Atopic Dermatitis (SCORAD) index, which is a combined index reflecting the extent, severity, and subjective symptoms of $A D$, was assessed in infants with $A D .{ }^{11}$ The study protocol was approved by the Institutional Review Board (IRB) of Asan Medical Center. Informed consent was provided by the parents of each infant and confirmed by the IRB.

\section{Questionnaires}

To investigate the presence of visible indoor damp stains and mold in the subjects' homes, the authors asked the parents to complete a questionnaire at 36 weeks of gestation and at 6 months. At each follow-up visit, the parents were asked, "Do you have visible damp stains and molds at home?" 12,13

\section{Sampling and analysis of indoor mold at home}

At 36 weeks of gestation, dust samples were collected from all of the participants of the COCOA birth cohort study from the bedroom where the pregnant woman spent most of her time, using an Electrolux (Electrolux ${ }^{\circledR}$, Stockholm, Sweden). Samples were taken at the same time of day and immediately frozen at $-70^{\circ} \mathrm{C}$. The mycobiomes of 20 randomly selected healthy infants and 20 infants with $A D$ enrolled in the prospective COCOA study were analyzed. Fungal DNA was extracted using the FastDNA SPIN kit for soil (Qbiogene; MP Biomedicals, Illkirch, France). Analysis of the environmental mycobiome at 36 weeks of gestation was performed using the Illumina MiSeq platform (Illumina ${ }^{\circledR}$, CA, USA). The diversity and composition of the indoor mycobiomes of the two groups were then compared.

\section{Measurement of total serum IgE levels}

Total serum IgE levels at 1 year of age was measured in all of the participants with blood samples using the ImmunoCAP system (ThermoFisher, Uppsala, Sweden). The lower detection limit was $2 \mathrm{kU} / \mathrm{L} .{ }^{14}$

\section{Data analysis}

Significant relationships were assessed using a logistic regression model adjusted for maternal age, maternal body mass index, maternal education level, sex, parental history of allergic diseases, and birth season. To identify the effect of mold exposure during pregnancy, data were adjusted for mold exposure in infancy, and to identify the effect of mold exposure in infancy, data were adjusted for mold exposure during pregnancy. The relationships between biomarkers and the relative abundance of a specific mold were analyzed using Pearson correlation tests. Data were analyzed using SPSS version 21.0 (SPSS Inc., Chicago, IL, USA). A p-value of 0.05 or less was considered significant.

\section{Results}

\section{Association between mold exposure and development of $A D$ according to time of exposure}

Prenatal mold exposure was associated with an increased risk of $A D$ at 1 year of age (adjusted odds ratio [aOR]: 1.36; 95\% confidence interval [95\% Cl]: 1.01-1.83), even when data were adjusted for postnatal mold exposure (Table 2). There was no association between the risk of $A D$ and mold exposure during the first year of life (aOR: $0.83 ; 95 \% \mathrm{Cl}$ : $0.61-1.13)$, even after adjusting for mold exposure during the prenatal period.

\section{Infant characteristics and mycobiome data}

The characteristics of the infants and data on the environmental mycobiome during pregnancy are shown in Table 3. For the 20 infants with AD, the SCORAD index at 1 year of age was $14.37 \pm 18.91$. The percentage of eosinophils in cord blood was significantly higher in infants with $A D$ than in healthy infants. There was no significant difference between the groups in terms of family history of allergic diseases.

\section{Comparison of total serum IgE levels at 1 year of age}

Total serum IgE levels were significantly higher in infants with $A D$ exposed to mold during pregnancy than in healthy 


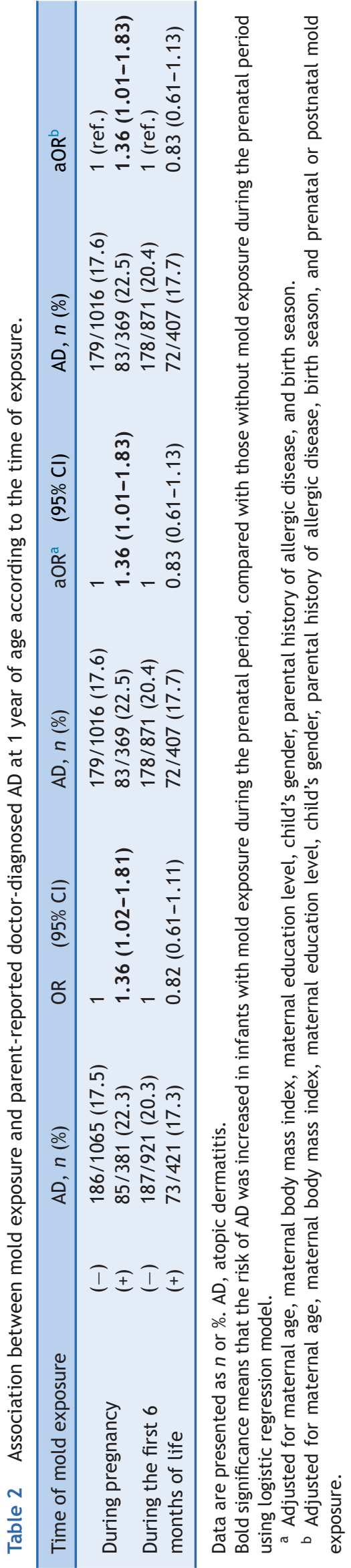

infants not exposed to mold (mean \pm standard deviation, $124.96 \pm 413.82 \mathrm{kU} / \mathrm{L}$ vs. $58.71 \pm 126.25 \mathrm{kU} / \mathrm{L} ; \quad p=0.021)$ (Fig. 1A). Even in infants with $A D$, total serum IgE was lower in those not exposed to mold during pregnancy $(64.98 \pm 197.99 \mathrm{kU} / \mathrm{L}$ vs. $124.96 \pm 413.82 \mathrm{kU} / \mathrm{L})$, although the difference was not significant. Log-transformed total serum IgE levels at 1 year of age in infants with $A D$ correlated with the SCORAD index at 1 year of age $(r=0.186$, $p=0.018$; Fig. 1B).

\section{Comparison of the mycobiome data between infants with $A D$ and healthy infants}

There was no significant difference in the diversity and richness score (Chao1, operational taxonomic units) for the indoor mycobiome at 36 weeks of gestation between 20 healthy infants and 20 infants with $A D$ (data not shown). The relative abundance of uncultured Ascomycota species was higher in infants with $A D(149.75 \% \pm 506.51 \%)$ than in healthy infants $(60.82 \% \pm 81.83 \%)$.

The relative abundance of uncultured Ascomycota species correlated with total serum IgE levels at 1 year of age $(r=0.613, p<0.001$; Fig. $1 C)$, but not with the SCORAD index, in all subjects and in infants with $A D$.

\section{Discussion}

This study demonstrated that mold exposure during the prenatal period is associated with an increased risk of $A D$ in infants enrolled in a prospective birth cohort study (COCOA); mold exposure during the postnatal period was not associated with the development of $A D$. Levels of total serum IgE in infants with $A D$ exposed to mold during the prenatal period were higher than those in healthy infants not exposed to mold during the fetal period; this was true even for AD infants not exposed to mold. The relative abundance of uncultured Ascomycota species in the home during pregnancy was higher in the case of infants with AD than in that of healthy infants, and correlated with total serum IgE levels at 1 year of age. This suggests that exposure to higher levels of indoor Ascomycota during the prenatal period might contribute to development of $A D$ in early life via lgE-mediated allergic inflammation. Thus, avoiding or limiting exposure to the environmental mycobiome during critical periods of development may help prevent development of $A D$ in early life.

Although the pathophysiology of $A D$ is not fully understood, defects in the skin barrier, dysfunctional immune responses, and environmental factors are thought to be major causes. ${ }^{15}$ Dysbiosis and colonization of the skin by specific microbiomes and fungi induce inflammation associated with $A D,{ }^{16}$ and interaction between the host and the microbiome can act as an immunomodulator. ${ }^{17}$ The results of the present study suggest that exposure to the environmental mycobiome, especially during critical developmental periods, affects development of $A D$.

Few studies have examined the mechanisms underlying the association between the environmental mycobiome and $A D$, or the effect of specific mycobiome components on the pathogenesis of $A D$, although the mycobiome is an important component of the human environment. ${ }^{12,18}$ 
Table 3 Characteristics of the study population and mycobiome data.

\begin{tabular}{|c|c|c|c|}
\hline Variable & $\begin{array}{l}\text { Healthy infants } \\
(n=20)\end{array}$ & $\begin{array}{l}\text { Infants with } A D \\
(n=20)\end{array}$ & $p$-Value ${ }^{a}$ \\
\hline Gestational age (weeks) & $39.18 \pm 1.22$ & $39.53 \pm 1.06$ & 0.339 \\
\hline Male, $n(\%)$ & $10 / 20(50.0)$ & $12 / 20(60.0)$ & 0.525 \\
\hline Birth weight, mean \pm SD (g) & $3088.33 \pm 264.63$ & $3043.58 \pm 849.39$ & 0.832 \\
\hline SCORAD index & NA & $14.37 \pm 18.91$ & NA \\
\hline Parental history of allergic diseases [yes, $n(\%)]$ & $12 / 20(60.0)$ & $12 / 19(63.2)$ & 0.839 \\
\hline Cord blood eosinophils (\%) & $2.53 \pm 1.60$ & $4.20 \pm 1.32$ & 0.011 \\
\hline Log-transformed cord blood total serum IgE level, mean \pm SD (kUA/L) & $-2.02 \pm 0.34$ & $-1.24 \pm 0.89$ & 0.012 \\
\hline Log-transformed total serum IgE level at 1 year of age, mean \pm SD (Kua/L) & $1.11 \pm 0.51$ & $1.43 \pm 0.56$ & 0.077 \\
\hline
\end{tabular}

AD, atopic dermatitis; $n$, number; NA, not applicable; SCORAD, SCORing Atopic Dermatitis; SD, standard deviation.

The cord blood eosinophil (\%) and log-transformed cord blood total serum IgE levels were significantly increased in infants with AD compared with healthy infants are denoted in bold.

a Mann-Whitney U-test.

A
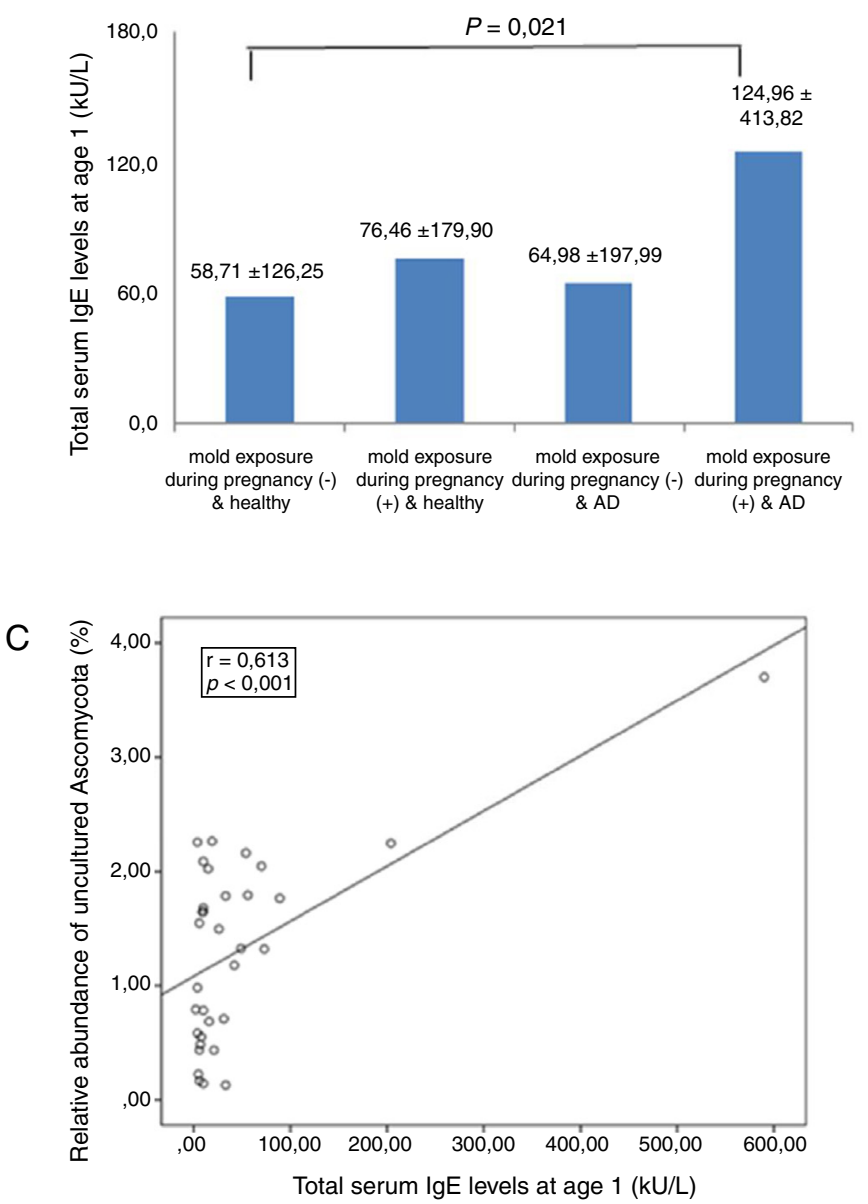

B

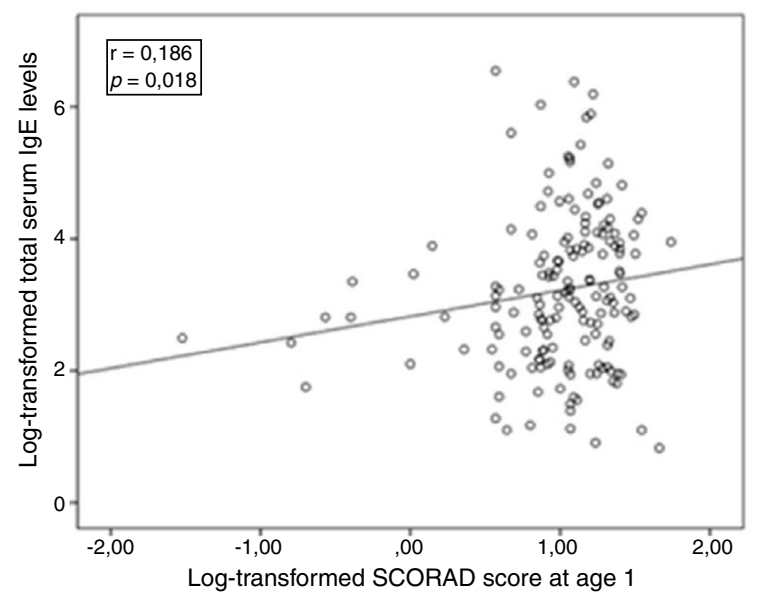

Figure 1 (A) Association between levels of total serum lgE according to mold exposure during pregnancy and atopic dermatitis. Data are expressed as the mean \pm standard deviation. (B) Correlation between the log-transformed SCORAD index at 1 year of age and log-transformed total serum IgE levels. (C) Correlation between the relative abundance of uncultured Ascomycota species in the environment at 36 weeks of gestation and total serum IgE levels at 1 year of age. 
Previous studies in $A D$ patients focused mainly on mold acting as an aeroallergen during development of respiratory allergic diseases and skin inflammation related to skin colonization by specific fungi, such as Malassezia species. 8,19 The mechanisms underlying mold-induced development of $A D$ might include sensitization to mold or triggering of immune responses directed against specific components of the mycobiome. However, few studies, particularly those stratified according to the timing of exposure, have examined the association between environmental mold exposure and $A D$; thus the underlying mechanisms remain unknown.

The result of the present study suggests that exposure to indoor mold during the prenatal period can affect the development of $A D$ via immunomodulation, possibly via IgE-related allergic inflammation. This is supported by the finding of higher levels of total serum IgE in the serum of infants with $A D$ exposed to mold during the prenatal period than in $A D$ infants lacking exposure. In addition, the authors previously reported that mold exposure during infancy is associated with increased total serum IgE levels, ${ }^{13}$ although the underlying mechanisms were not identified. The results of the present and previous studies suggest that exposure to environmental mold in early life may induce IgE-mediated allergic inflammation; however, the present study found no significant correlation between the severity of $A D$ and the relative abundance of uncultured Ascomycota $(r=0.347$, $p=0.399$, data not shown). This might suggest a role for specific mycobiome components as inducers of IgE-mediated allergic inflammation during development of AD. Further studies are needed to identify the mechanisms underlying the association between mold exposure during the fetal period and development of $A D$ in early life.

Exposure to environmental factors during the prenatal period can affect the developing immune system. ${ }^{20}$ Prenatal maternal stress and diverse environmental factors can cause changes in gene expression via epigenetic mechanisms, especially during critical developmental periods, thereby affecting the development and differentiation of the immune system. ${ }^{20-22}$ Mold exposure in itself can cause allergic immune responses, and mold components such as proteases can act as dermatologic irritants or inducers of allergic inflammation in the airway. ${ }^{23,24}$ Based on the above findings, the altered maternal immune response due to mold exposure during pregnancy might affect the development of immune system in the offspring and thereby might be related to development of $A D$ in infants. ${ }^{25}$ The present study found no significant differences in the diversity of the mycobiome between healthy infants and infants with $A D$ during the prenatal period; however, the relative abundance of specific fungi, such as uncultured Ascomycota, in the home environment during the prenatal periods was higher in infants with $A D$ than in healthy infants. The results of the present study suggest that exposure to specific mycobiome components, rather than to mold itself, particularly during critical developmental periods, may be associated with development of $A D$ during infancy. Further large-scale studies are needed to confirm these results.

A protein component of Ascomycota can bind and modulate mRNAs. ${ }^{26}$ Also, fungal polysaccharides, including those from Ascomycota, can induce production of free radicals and inflammation-associated cytokine production. ${ }^{27}$
In a previous study, the authors demonstrated that mold exposure was associated with development of $A D$ via Th2 cytokine-mediated generation of reactive oxygen species (ROS). ${ }^{12}$ Imbalances in ROS generation can also affect gene expression. ${ }^{28}$ Taken together, these results suggest that exposure to indoor molds, including Ascomycota, during the prenatal period can affect development of $A D$ via immunomodulatory effects. ${ }^{13}$

This study has some limitations. First, mold exposure was determined using a questionnaire from the prospective birth cohort study (COCOA). However, a previous study showed that determining mold exposure by questionnaire or by measurement of total airborne culturable spores yields similar results. ${ }^{29}$ Second, indoor mycobiome analyses were limited by the small sample size; however, an association was identified between specific mycobiome components and allergic inflammation. A strength of the study is that it is a prospective, general population-based birth cohort study. The data will help determine the role of indoor mold exposure during critical periods in development of allergic diseases, including $A D$. In conclusion, exposure to indoor mold during the fetal period is associated with development of $A D$ in early life, possibly via IgE-mediated allergic inflammation. Therefore, avoiding or limiting exposure to mold during the prenatal period may help prevent $A D$ in infancy.

\section{Funding}

This study was supported by the Korean Health Technology R\&D Project, Ministry of Health \& Welfare, Republic of Korea (grant No. HI13C16740000), and by the Research of Korea Centers for Disease Control and Prevention (2008-E33030-00, 2009-E33033-00, 2011-E33021-00, 2012E33012-00, 2013-E51003-00, and 2014-E51004-00).

\section{Conflicts of interest}

The authors declare no conflicts of interest.

\section{References}

1. Asher MI, Montefort S, Bjorksten B, Lai CK, Strachan DP, Weiland SK, et al. Worldwide time trends in the prevalence of symptoms of asthma, allergic rhinoconjunctivitis, and eczema in childhood: ISAAC phases one and three repeat multicountry cross-sectional surveys. Lancet. 2006;368:733-43.

2. Kim YH, Lee E, Cho HJ, Yang SI, Jung YH, Kim HY, et al. Association between menarche and increased bronchial hyper-responsiveness during puberty in female children and adolescents. Pediatr Pulmonol. 2016;51:1040-7.

3. Williams H, Stewart A, von Mutius E, Cookson W, Anderson HR. International Study of Asthma and Allergies in Childhood (ISAAC) Phase One and Three Study Groups. Is eczema really on the increase worldwide? J Allergy Clin Immunol. 2008;121:947-54, e15.

4. Horimukai K, Morita K, Narita M, Kondo M, Kitazawa H, Nozaki $M$, et al. Application of moisturizer to neonates prevents development of atopic dermatitis. J Allergy Clin Immunol. 2014;134:824-30, e6.

5. Lee JY, Seo JH, Kwon JW, Yu J, Kim BJ, Lee SY, et al. Exposure to gene-environment interactions before 1 year of age may favor 
the development of atopic dermatitis. Int Arch Allergy Immunol. 2012;157:363-71.

6. Kim WK, Kwon JW, Seo JH, Kim HY, Yu J, Kim BJ, et al. Interaction between IL13 genotype and environmental factors in the risk for allergic rhinitis in Korean children. J Allergy Clin Immunol. 2012;130:421-6, e5.

7. Bjorksten B, Sepp E, Julge K, Voor T, Mikelsaar M. Allergy development and the intestinal microflora during the first year of life. J Allergy Clin Immunol. 2001;108:516-20.

8. Harada K, Saito M, Sugita T, Tsuboi R. Malassezia species and their associated skin diseases. J Dermatol. 2015;42:250-7.

9. Yang HJ, Lee SY, Suh DI, Shin YH, Kim BJ, Seo JH, et al. The cohort for childhood origin of asthma and allergic diseases (COCOA) study: design, rationale and methods. BMC Pulm Med. 2014;14:109.

10. Weidinger S, Novak N. Atopic dermatitis. Lancet. 2016;387:1109-22.

11. Kunz B, Oranje AP, Labreze L, Stalder JF, Ring J, Taieb A. Clinical validation and guidelines for the SCORAD index: consensus report of the European task force on atopic dermatitis. Dermatology. 1997;195:10-9.

12. Kim HJ, Lee E, Lee SH, Kang MJ, Hong SJ. Mold elicits atopic dermatitis by reactive oxygen species: epidemiology and mechanism studies. Clin Immunol. 2015;161:384-90.

13. Yu HS, Kang MJ, Kwon JW, Lee SY, Lee E, Yang SI, et al. Claudin1 polymorphism modifies the effect of mold exposure on the development of atopic dermatitis and production of IgE. J Allergy Clin Immunol. 2015;135:827-30, e5.

14. Kim HB, Ahn KM, Kim KW, Shin YH, Yu J, Seo JH, et al. Cord blood cellular proliferative response as a predictive factor for atopic dermatitis at 12 months. J Korean Med Sci. 2012;27:1320-6.

15. Nomura T, Kabashima K. Advances in atopic dermatitis in 2015. J Allergy Clin Immunol. 2016;138:1548-55.

16. Kobayashi T, Glatz M, Horiuchi K, Kawasaki H, Akiyama H, Kaplan DH, et al. Dysbiosis and Staphylococcus aureus colonization drives inflammation in atopic dermatitis. Immunity. 2015;42:756-66

17. Kinross JM, Darzi AW, Nicholson JK. Gut microbiome-host interactions in health and disease. Genome Med. 2011;3:14.

18. Cui L, Morris A, Ghedin E. The human mycobiome in health and disease. Genome Med. 2013;5:63.
19. Mendell MJ, Mirer AG, Cheung K, Tong M, Douwes J. Respiratory and allergic health effects of dampness, mold, and dampnessrelated agents: a review of the epidemiologic evidence. Environ Health Perspect. 2011;119:748-56.

20. Prescott S, Saffery R. The role of epigenetic dysregulation in the epidemic of allergic disease. Clin Epigenet. 2011;2: 223-32.

21. Nemoda Z, Szyf M. Epigenetic alterations and prenatal maternal depression. Birth Defects Res. 2017;109:888-97.

22. Nye MD, Fry RC, Hoyo C, Murphy SK. Investigating epigenetic effects of prenatal exposure to toxic metals in newborns: challenges and benefits. Med Epigenet. 2014;2:53-9.

23. Bush RK, Portnoy JM, Saxon A, Terr Al, Wood RA. The medical effects of mold exposure. J Allergy Clin Immunol. 2006;117:326-33.

24. Porter P, Susarla SC, Polikepahad S, Qian Y, Hampton J, Kiss $A$, et al. Link between allergic asthma and airway mucosal infection suggested by proteinase-secreting household fungi. Mucosal Immunol. 2009;2:504-17.

25. Hinz D, Bauer M, Roder S, Olek S, Huehn J, Sack U, et al. Cord blood Tregs with stable FOXP3 expression are influenced by prenatal environment and associated with atopic dermatitis at the age of one year. Allergy. 2012;67:380-9.

26. Wilinski D, Qiu C, Lapointe CP, Nevil M, Campbell ZT, Tanaka Hall TM, et al. RNA regulatory networks diversified through curvature of the PUF protein scaffold. Nat Commun. 2015; 6:8213.

27. Osinska-Jaroszuk M, Jarosz-Wilkolazka A, Jaroszuk-Scisel J, Szalapata K, Nowak A, Jaszek M, et al. Extracellular polysaccharides from Ascomycota and Basidiomycota: production conditions, biochemical characteristics, and biological properties. World J Microbiol Biotechnol. 2015;31: 1823-44.

28. Dalton TP, Shertzer HG, Puga A. Regulation of gene expression by reactive oxygen. Annu Rev Pharmacol Toxicol. 1999;39:67-101.

29. Belanger K, Beckett W, Triche E, Bracken MB, Holford T, Ren P, et al. Symptoms of wheeze and persistent cough in the first year of life: associations with indoor allergens, air contaminants, and maternal history of asthma. Am J Epidemiol. 2003;158: 195-202. 